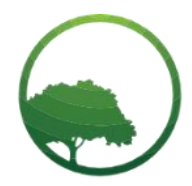

Research in Business \& Social Science

IJRBS VOL 11 NO 1 (2022) ISSN: 2147-4478

\title{
Factors affecting sales of international solar mini-grids in Tanzania mainland
}

\author{
(D) Yassin Teikwa ${ }^{(a)}$ (D) Chacha Magasi ${ }^{(b) *}$ \\ ${ }^{(a, b)}$ College of Business Education, Dodoma, Tanzania
}

\author{
A R T I CLE IN F O \\ Article history: \\ Received 02 January 2022 \\ Received in rev. form 03 Feb. 2022 \\ Accepted 05 February 2022 \\ Keywords: \\ Customer purchase, government \\ policies, international solar mini-grids, \\ Sales, Tanzania Mainland \\ JEL Classification: \\ O15
}

\begin{abstract}
A B S T R A C T
The research purpose was to investigate factors that affect Sales of International Solar Mini-Grids in Tanzania Mainland. The motivation for the study was because there was evidence of a decline in sales of International Solar Mini-Grids in Mwanza, Dar es Salaam, and Arusha regions. The study used a sample size of 70 respondents, a cross-section survey, primary data and secondary data. The study used the mixed methods research design. Multiple linear regression was employed in quantitative data analysis with the aid of SPSS. Thematic analysis was conducted to derive themes from the qualitative data and information obtained was utilized to supplement the quantitative data. The study revealed that government policies, more specifically energy policy, significantly affect sales of International Solar Mini-Grids in Tanzania Mainland. In addition, the regulatory framework, particularly tariff, significantly affects sales of International Solar Mini-Grids. Also, customers' purchasing tendencies were significantly affecting the sales of International Solar Mini-Grids. The findings imply that ignoring the factors affecting sales of International Solar Mini-Grids in Tanzania Mainland might worsen the power sector and solar Mini-Grids sustainability. This work recommends that to foster the sales of International Solar Mini-Grids, the government should have a suitable energy policy and regulatory framework geared to enhance the marketability of electricity and enhance customer purchase. The study contributes to knowledge by offering empirical evidence on renewable energy that will be of paramount importance to other renewable energy stakeholders.
\end{abstract}

() 2022 by the authors. Licensee SSBFNET, Istanbul, Turkey. This article is an open access article distributed under the terms and conditions of the Creative Commons Attribution (CC BY) license (http://creativecommons.org/licenses/by/4.0/).

\section{Introduction}

Energy from electricity plays a great role in industrial, commercial and residential establishments (World Bank, 2019). Global statistics show that a population of 1.1 billion do not have electricity access following high costs (Malhotraa et al, 2017; IEA and World Bank, 2019). The eighth Sustainable Development Goal (SDG) advocates access to renewable, safe and widely available energy sources such as solar mini-grids for all. In response to this objective, the government of Tanzania incentivized and enacted various policies and laws in favour of the power sector and private investors participation (Al-ghussain. et al, 2020; World Bank, 2019; EWURA, 2020). All aforementioned measures have been done to ensure proximity of power in the country including remote areas and islands. However, International Solar mini-grids operating in Tanzania Mainland has been reporting on the decline of sales and there is no thorough study carried out in investigating the factors affecting the sales. Ignorance of such factors in question might worsen the sector as demoralization of investors may affect the economy of rural areas and islands populations. Mainali (2012) noted that renewable energy technologies are at the centre of solving the challenges of rural electrification. However, higher operation and set-up costs, and institutional factors seem to hinder the process. Furthermore, political regulations and policy, social, sustainability, safety and financial capital factors such as customer purchase ability were found to affect the sector (Al-ghussain et al., 2020; Malhotraa et al., 2017; Williams et al., 2015; Hazelton et al., 2014 \& Franz et al., 2014). In this regard, limited relevant studies in

\footnotetext{
* Corresponding author. ORCID ID: 0000-0003-0376-8886

(C) 2022 by the authors. Hosting by SSBFNET. Peer review under responsibility of Center for Strategic Studies in Business and Finance.

https://doi.org/10.20525/ijrbs.v11i1.1556
}

Citation: Teikwa, Y., \& Magasi, C. (2022). Factors affecting sales of international solar mini-grids in Tanzania mainland. International Journal of Research in Business and Social Science (2147-4478), 11(1). 
the Tanzanian context compelled the researchers to investigate factors affecting sales of International Solar Mini-Grids in Tanzania Mainland.

Tanzania like most countries needs renewable energy like solar power mini-grids (Samoita et al, 2020) as the catalyst of green development. Out of 56 million people of Tanzanians, $78.4 \%$ have access to electricity and only $37.7 \%$ have been connected to electricity (EWURA, 2020). Solar mini-grids came into existence following the incapacitation of Tanzania Electric Supply Company Limited (TANESCO). Various enabling initiatives have been made by the government to enhance the business of solar mini-grids by establishing regulatory framework, incentivizing the sector and enacting relevant policies and laws. It was expected that solar mini-grid investment would be profitably done and its performance reflected in sales size, however, this has not been the case. International Solar Mini-Grids operating in Tanzania Mainland has been reporting on the decline of their sales particularly starting on the second quarter of the year 2020 where PowerGen Renewables Energy Limited, reported a drop of 83\% from TZS: 36,417,221.31 to 6,079,845.85 (PowerGen, 2020), Jumeme Rural Power Supply Company Limited 86\% from TZS: 52,918,221.44 to TZS: 7,656,880.27 (JUMEME, 2020), and Engie Power Corner Tanzania Limited 54\% from TZS: 28,000,000 to TZS: 13,000,000 (EPT, 2020). The three (03) Mini-Grids represent 10,062 customers out of a total of 11,193 which is equivalent to $90 \%$. Various studies mention that institutional, political factors, social-cultural, technological and economic factors such as customer purchase ability affect the electricity sector (Al-ghussain. et al, 2020; Malhotraa et al, 2017; Williams et al, 2015). Similarly, it has been mentioned that regulatory framework, customer purchase, and policies affect the performance of mini-grids in Tanzania mainland (Bloomberg, 2020). However, there is little information and literature to explain how the aforementioned factors affect the sales performance of International Solar Mini-Grids in Tanzania Mainland. Ignorance of the foretasted factors might worsen the power sector. The study, therefore, examined factors affecting sales of International Solar Mini-Grids in Tanzania Mainland. Specifically, the study; determined the effect of regulatory framework on sales of International Solar Mini-Grids; examined the effect of customer purchase on sales of International Solar Mini-Grids, and assessed the effect of government policies on sales of International Solar Mini-Grids in Tanzania Mainland.

\section{Literature Review}

\section{Theoretical and Empirical Review}

Theory used is Stakeholders Theory developed by Freeman (1984). It designates the way numerous stakeholders impacts performance of the organization. Stakeholders include suppliers, the public, customers, society, media, employees, investors, policymakers, regulators, and development partners (Okello \& Kihara,2019). The relevance of a theory is evidenced by its capability to explain various stakeholders in which solar mini-grid business is involved including; Energy and Water Utilities Regulatory Authority (EWURA) as energy regulator, customers who pay for the services, investors, and the Ministry of Energy as a policy maker. Therefore, in this study, regulatory framework of which tariff is its subset, customer purchase, and government policies including energy policy were independent variables while sales of International Solar Mini-Grids were the dependent variable. To get more information on the factors affecting sales of International Solar Mini-Grids, empirical review was then done.

The study examined the effect of regulatory framework on sales of International Solar Mini-Grids in Tanzania. Tanzania is considered to have developed strong regulations for the sustainability of mini-grids as compared to the remaining Sub-Saharan countries in Africa (Bloomberg, 2020). Nevertheless, current movements have called the commitment of the government into question with complaints from investors on the weak execution of regulations including the tariff. Al-ghussain et al. (2020) observed that political regulations of which tariff is its subset affect sales of the solar mini-grid projects in Mozambique. This observation was supported by the work of Abase (2018) in Ghana. However, both studies were less relevant to Tanzania as they were conducted in Mozambique and Ghana respectively. Studies conducted in Kenya found that solar mini-grid energy solutions are affected by the shortness of lifespan of the project, government and society support (Samoita et al., 2020; Ponde et al., 2019).

Besides, it was noted that the regulatory framework including tariffs affected the functionality of the solar mini-grids in Kenya. It is not known to what extent EWURA as an energy regulator affects sales of International Solar Mini-Grids in Tanzania Mainland. The researchers were eager to investigate factors affecting sales of International Solar Mini-Grids in the Tanzania Mainland context. In the case of Tanzania, Bishoge et al. (2018) found that government regulations enforcement had a problem in that setting of price or tariff was inconsistent. Therefore, it is evident that government regulations affect the investment of solar mini-grid in Tanzania. Even though, the research vicinity was in Tanzania, yet, this study failed to unfold factors affecting sales of International Solar Mini-Grids in Tanzania Mainland. Thus, its findings were too general and vague to be considered. Thus, the conclusive study on factors affecting sales of international solar mini-grid in Tanzania is limited. Instead, Bishoge et al (2018) considered the effect of customer purchase on sales of solar mini-grids which indeed was found to affect the sales of International Solar Mini-Grids in Tanzania Mainland.

The decision-making procedures and actions of people who buy and use things are referred to as customers' purchase tendencies (Kotler, 2012). Customer purchase tendency is a demographic factor that shows the ability of customers to pay for the electricity liabilities. Mainali (2012) found that income poverty, lack of credits, inadequate government subsidy and institutional credibility were hindering electricity proximity and access in Nepal. This study was significant in that it provided factors causing unsatisfactory sales of solar mini-grids. However, this study was conducted in Nepal thus, its findings may not apply to Tanzania. Furthermore, Malhotraa et al. (2017) observed that cost of capital for renewable energy was affecting the investment of solar mini-grids. This study 
has pinpointed factors affecting the sale of solar mini-grids. Moreover, the study has been done in India and not in Tanzania. Based on this view, study findings cannot be generalized for the Tanzanian context. Bloomberg (2020) argued that solar mini-grids are designed for low-income families and that their customers demand is changeable as their income depends on agriculture. Also, weather fluctuating conditions and crop yield seasonality affects their capacity to pay for electricity bills, hence the sales of electricity are affected. Nevertheless, connectivity of government policies with customer purchase tendencies and ultimately alteration of sales of International Solar Mini-Grids have not been covered by Bloomberg (2020). Government policies were also suggested to affect the sales of Solar Mini-Grids in Tanzania Mainland.

The policy is a government deliberate act that amends or impacts the society or economy (Barrett, 2006). This implies that the government policy sets the mannerism on appropriate problem addressing by either encouraging or discouraging certain actions to attain the goal intended. Liu et al. (2019) related the government supports to the selected energy firms' performance in China. Government subsidies proved to have a constructive financial performance effect on private enterprises than they do on public enterprises. The study suggested that government should correct the subsidy policy for sustainable energy enterprises performance. Mainali (2012) revealed many factors which affect sales of solar mini-grids in Nepal but, Liu et al. (2019) observed that the government policy of subsidies was highly emphasized.

Despite the suitability of the discussed studies, it is not known upon using other approaches apart from panel data whether the findings will remain stable. Likewise, China and Nepal differ considerably from Tanzania; therefore, such studies' findings cannot be generalized to the Tanzania context. Al-ghussain et al. (2020) found that in Mozambique, political regulations, low capital, and policy affects the sales of the solar mini-grids. Also found that social, sustainability and safety issues affect too. Abase (2018) and Al-ghussain et al. (2020) agree with the opinion that installation of the solar mini-grid system is cheaper compared to other power sources but, without government subsidy, credit facility and promotion by experts, the sector cannot be fruitful enough. This implies that there is a need to ensure that government policies on energy should be geared towards financing, offering credit facilities to investors and promotion of electricity to citizens so that they may adopt the technology and ultimately purchase the power. Similar to Al-ghussain et al. (2020), who conducted a study in Mozambique, Abase (2018) studied the topic in Ghana in West Africa. Thus, both pieces of research' findings were little relevant to Tanzania due to differences in vicinities.

Ponde et al. (2019) found that solar mini-grid energy performance in Kenya was affected by the shortness of lifespan of the project, lack of government subsidies and little support from society. Like the two studies above in Mozambique and Ghana, this study has failed to link the noted factors with sales of the solar mini-grid. Similarly, Samoita et al. (2020) in Kenya found similar research findings to Ponde et al. (2019). So long Tanzania is different from other countries where studies were carried out institutionally, demographically, economically, politically and socio-culturally, thus, research findings are of little relevance to the Tanzanian context.

In this way, the research gap that has been described in this document remains unaddressed in Tanzania. The following hypotheses guided this study:

\section{H1: The regulatory framework does not affect sales of International Solar Mini-Grids in Tanzania Mainland; \\ H2: The customer purchase does not affect the sales of International Solar Mini-Grids in Tanzania Mainland; and \\ H3: The Government policies do not affect sales of International Solar Mini-Grids in Tanzania Mainland.}

From theoretical and empirical review, the research gaps were established. International investors of solar mini-grids are lamenting the recent persistent decline of sales. However, factors behind such claimed sales decline have not yet been invested in Tanzania Mainland. The failure to ascertain such factors is attributed to the absence of conclusive and comprehensive studies regarding factors affecting sales of International Solar Mini-Grids in Tanzania Mainland. This is the research knowledge gap required to be addressed in this study.

The conceptual model connects many variables derived from topic themes, research results, and hypotheses used throughout the researcher's systemization of knowledge (Adom et al., 2018). It details the researchers' explanation of how the problem of the research can be addressed by showing the relationship among variables of study (Mensah et al., 2020). With this in view, Customer purchase, regulatory framework, and government policies are independent variables.

The dependent variable is sales. The researchers believe that customer purchase, regulatory framework, and government policies have a significant effect on the sales of the International Solar Mini-Grids in Tanzania Mainland as shown by Figure 1. 


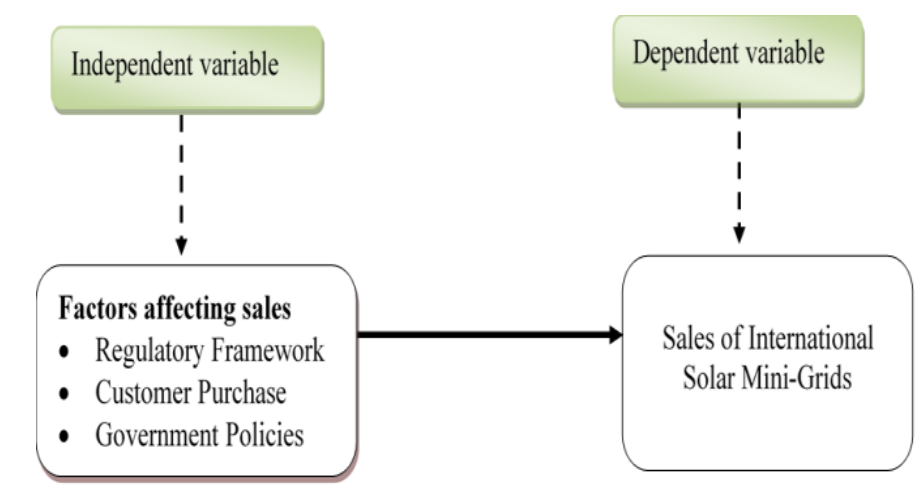

Figure 1: The conceptual Framework; Source: Literature Review (2021)

\section{Research and Methodology}

The research viewpoint is positivist because the study aims at discovering the truth behind the scene on how causes, namely regulatory framework, customer purchase, and government policies determine the outcome, namely sales (Creswell, 2014). Correlation design was applied as independent variables, namely regulatory framework, customer purchase, and government policies can be correlated with a dependent variable, namely sales (Kothari, 2015). This study applied the mixed methods research design where objective theories were tested by examining dependent and independent variables relate. This study used a cross-sectional research type because the collection of data from the study area was at one point in time (Creswell, 2014). The survey research method was used as it comprises usage of uniform questionnaires in gathering data concerning people's likings, behaviours, and feelings in a systematic manner (Kothari, 2015). The collected quantitative data were then converted into numerals and analyzed using the multiple linear regression method to understand the problem of the research (Creswell, 2014). To get in-depth knowledge particularly on the regulatory framework, and government policies, the study conducted in-depth interview, involved a review of relevant documents and records regarding energy regulation and policies to provide supportive information to quantitative findings. This work was done in Mwanza, Dar es Salaam, and Arusha regions, where headquarters of the three International Solar Mini-Grids are located and hence owner and head office staff were found for interview. The study also was conducted in Lake Zone regions where branch office staff were found.

Population remained to be the owner and respective staff of the three International Mini-Grids in Tanzania Mainland. The units of analysis were the owner and staff of the International Solar Mini-Grids. Seventy (70) owners and staff were secured, namely; PowerGen Renewables Energy Limited: 25 respondents; Jumeme Rural Power Supply Company Limited:19 respondents and Engie Power Corner Tanzania Limited: 26 respondents. Total population has been regarded as the sample size which is 70 respondents because size of population we are interested in is typically very small, therefore, not considering the whole population would result in missing significant information the research intends to understand (Kumar, 2011).

Primary data were collected through questionnaires whereas secondary data were secured from a review of relevant documents and records. Five-points Likert Scale was adapted in grading responses in this survey research since it applied a comparable approach (IBRD, 2019). Seventy (70) structured questionnaire sets were self-administered to the earmarked respondents in Tanzania Mainland. Questionnaires comprised both open and closed-ended questions. Closed-ended questionnaires had five-point Likert scale ranging from " $1=$ strongly agree" to " $5=$ strongly disagree" while 2,3 and 4 are scaled as agree, neural, and disagree respectively. Besides, few open-ended questions were employed to apprehend a detailed understanding of the subject matter. Customer purchase data gathered through questionnaires were analysed quantitatively. In addition, regulatory framework and government policies data collected through questionnaire and document review were analysed quantitatively and qualitatively respectively to get in-depth knowledge on why respondents responded in such a manner to the questionnaire. Data collected were summarized, coded and analyzed using multiple linear regression method which is suitable for showing variable correlation (Kothari, 2015). The equation 1 was used to estimate the relationships between predicators and an independent variable.

$$
Y=\beta_{0}+\beta_{1} X_{1}+\beta_{2} X_{2}+\beta_{3} X_{3}+\varepsilon
$$

Where:

$Y=$ Sales of solar mini-grids; $\beta_{0}, \beta_{1}, \beta_{2}$, and $\beta_{3}$ are coefficients or constants; $X_{1}=$ regulatory framework, $X_{2}=$ government policies, $\mathrm{X}_{3}$ customer purchase and $\varepsilon=$ error income level.

Given the well-developed corporate governance framework in International Solar Mini-grids Companies, an in-depth interview was employed to collect qualitative data by using the purposive sampling technique from the six selected respondents of PowerGen 
Renewables Energy Limited, Jumeme Rural Power Supply Company Limited and Engie Power Corner Tanzania Limited. Thematic analysis was conducted to derive themes from the qualitative data and information obtained was utilized to supplement the quantitative data. Thus, qualitative data were transcribed into texts and then relevant themes were developed and the findings were matched with relevant numerical findings in this study and other empirical literature elsewhere.

\section{Findings}

\section{Reliability and Validity}

In measuring reliability of the ordered questionnaire, this study computed Cronbach alpha. In attaining this, three questionnaires were subjected to arbitrarily designated International Solar Mini-Grids in Tanzania Mainland. Results conclude that all variables are well trusted since the attained were more than 0.7 and the same was used as reliability hurdle rate as per Table 1 .

Table 1: Reliability Results

\begin{tabular}{lll}
\hline Variable & $\boldsymbol{\alpha}=$ Alpha & Comment \\
\hline Regulatory Framework & 0.7543 & Reliable \\
Customer Purchase & 0.7987 & Reliable \\
Government Policies & 0.7112 & Reliable \\
\hline
\end{tabular}

Source: Researchers own constructs 2021

Table 2: Kaiser-Meyer-Olkin (KMO) test Interpretation Range

\begin{tabular}{ll}
\hline Ranges & Interpretation \\
\hline 0.90 's & Marvelous \\
0.80 's & Meritorious \\
0.70 's & Middling \\
0.60 's & Mediocre \\
0.50 's & Miserable, \\
Below 0.50 & Unacceptable \\
\hline
\end{tabular}

Source: $\mathrm{Wu}, \mathrm{Yu}, \&$ Weng (2012)

Given that KMO Measure met the minimum criteria of Sampling Adequacy as per Table 3, therefore the researcher had not faced the problem necessitating examining the Anti-Image Correlation Matrix.

Table 3: Kaiser-Meyer-Olkin Measure of Sampling Adequacy

\begin{tabular}{|c|c|}
\hline Kaiser-Meyer-Olkin Measure of Sampling Adequacy & 0.771 \\
\hline Bartlett's Test of Sphericity & 21.93 \\
\hline Df & 6.0 \\
\hline Sig. & 0.001 \\
\hline
\end{tabular}

Source: Researchers (2021)

\section{Testing Research Hypotheses}

Linearity assumption was first tested to know if it meets the assumption criterion. Dependent Variable (DV) and Independent Variables (IV) affiliation can correctly be approximated by Standard multiple regression if linear relationships exist. If affiliation is not linear, results will under-estimate the true relationship. Figure 2 shows scatterplots of residuals that indicate curvilinear and linear relationships. 


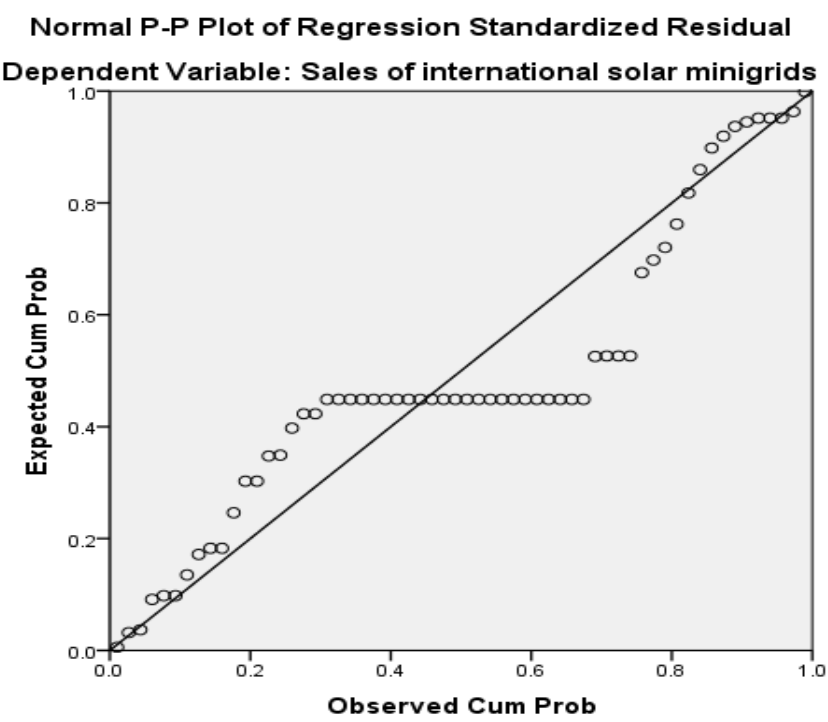

Figure 2: Scatter plots of Residuals Indicating Curvilinear and Linear Relationships; Source: Researchers' constructs 2021.

Normality and multicollinearity assumptions were also tested. The assumption in multiple regression is that residuals are normally spread. No Multicollinearity-Multiple regression adopts that independent variable are not highly correlated with each other. In this hypothesis, Variance Inflation Factor (VIF) values are tested. Several authors recommended a formal detection-tolerance or variance inflation factor (VIF) for multicollinearity: where $\mathrm{R}^{2}$ is the coefficient of determination of regression of explanator $\mathrm{j}$ on all the other explanatory. A tolerance of less than 0.20 or 0.10 and/or a VIF of 5 or 10 and above indicates a multicollinearity problem.

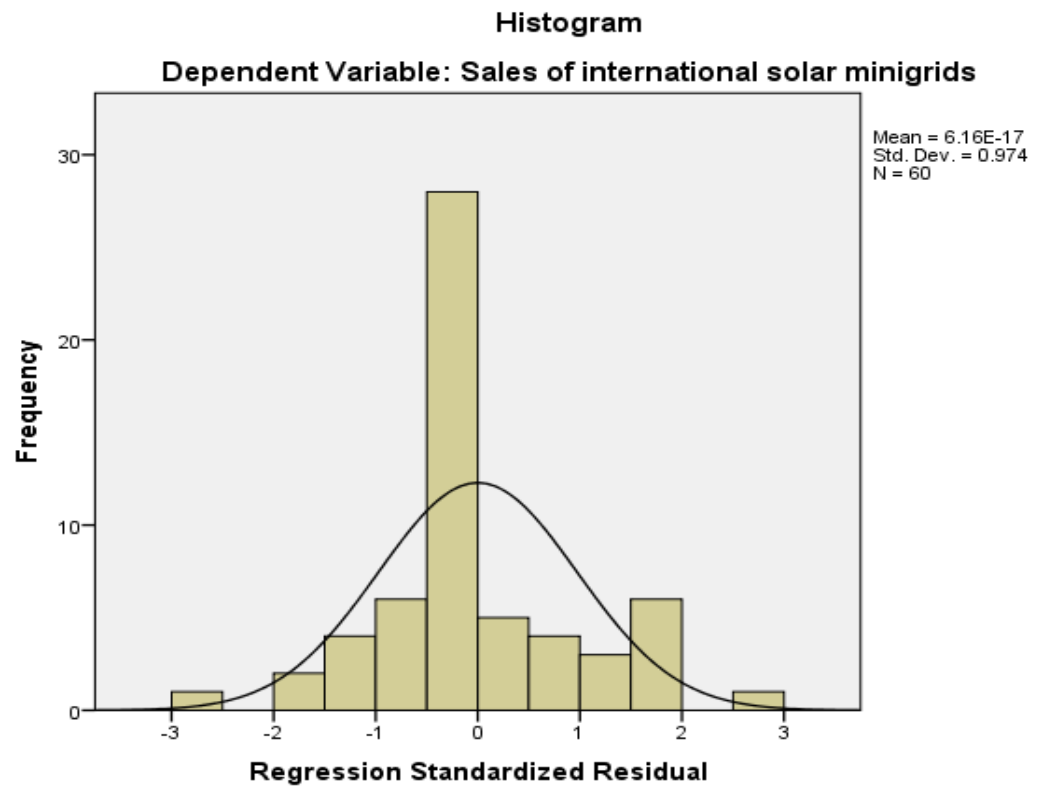

Figure 3: Variance Inflation Factor (VIF) Values; Source: Filed Data 2021

Results in Figure 3 revealed no multicollinearity between independent variables. Indexes of tolerance stood at 0.771 to 0.701 . Also, Variance Inflation Factor (VIF) stood at below 1.428. Tolerance is expressed as total inconsistency of designated Independent Variables (IV) that are not clarified by additional IV. VIF is the inverse of tolerance value (Hair et.al. 2010:227). This is from the individual independent variable as 1 - R2. Tolerance value from 0 to 1 , means it is low, hence there is the existence of Multicollinearity (Hair et.al. 2010: 227-228). Hair et.al (2010: 227) proposes a 0.10 tolerance value which is equivalent to a VIF of 10 to be a normal cut-off edge.

Correlational analysis was also done to ascertain if multiple linear regression assumptions were met. This is another assumption of multiple regression in which analysis in multiple linear regression necessitates that autocorrelation of data is slight or not at all. Autocorrelation happens once residuals are not independent (Hair et.al. 2010:227). Durbin-Watson d test is used to test the null hypothesis that the residuals are not linearly auto-correlated. While d can assume values between 0 and 4, values around 2 indicate 
no autocorrelation. Normally, Durbin-Watson at 1.5 is considered as the rule of thumb. In this study, it was noted that the DurbinWatson test 2.121 indicated that there was no autocorrelation in the data. For this reason, the choice of this method was appropriate.

\section{Coefficients of multiple linear analysis}

The determination of the research hypothesis was testing the truth of the research hypothesis whether the regulatory framework, customer purchase, and Government policies can affect sales of International Solar Mini-Grids in Tanzania Mainland. Enter multiple regression method was used to test the above null hypothesis and study results show that regulatory framework, customer purchase, and Government policies can affect sales of International Solar Mini-Grids in Tanzania Mainland as shown in Tables 4 and 5.

Table 4: Model Summary ${ }^{\mathrm{b}}$

\begin{tabular}{llllll}
\hline Model & R & R Square & $\begin{array}{l}\text { Adjusted } \\
\text { Square }\end{array}$ & $\begin{array}{l}\text { R } \\
\text { Std. Error of the } \\
\text { Estimate }\end{array}$ & Durbin-Watson \\
\hline 1 & $.779^{\mathrm{a}}$ & .607 & .586 & .559 & 2.121 \\
\hline
\end{tabular}

a. Predictors: (Constant), Effect of government policies, Effect of customer purchase, Effect of regulatory framework

b. Dependent Variable: Sales of international solar mini-grids

Source: Researchers' constructs 2021

Table 4 indicates that adjusted $\mathrm{R}^{2}$ for the overall model was 0.586 . This indicates that independent variables contribute to $58.6 \%$ change in sales. Thus, variables of choice (regulatory framework, customer purchase and government policies) have a significant effect on the sales of international solar mini-grids in Tanzania Mainland.

Table 5: Coefficients

\begin{tabular}{|c|c|c|c|c|c|c|c|c|}
\hline \multirow[t]{2}{*}{ Model } & \multicolumn{2}{|c|}{$\begin{array}{l}\text { Unstandardized } \\
\text { Coefficients }\end{array}$} & \multirow{2}{*}{$\begin{array}{l}\text { Standardized } \\
\text { Coefficients } \\
\text { Beta }\end{array}$} & \multirow[t]{2}{*}{$\mathbf{t}$} & \multirow[t]{2}{*}{ Sig. } & \multicolumn{3}{|c|}{ Collinearity Statistics } \\
\hline & B & Std. Error & & & & $\begin{array}{l}\text { Zero- } \\
\text { order }\end{array}$ & Tolerance & VIF \\
\hline (Constant) & .144 & .185 & & .781 & .002 & & & \\
\hline $\begin{array}{l}\text { Effect of regulatory } \\
\text { framework }\end{array}$ & .037 & .083 & .042 & .442 & .001 & .392 & .771 & 1.297 \\
\hline $\begin{array}{l}\text { Effect of customer } \\
\text { purchase }\end{array}$ & .217 & .083 & .234 & $\begin{array}{l}2.62 \\
0\end{array}$ & .001 & .464 & .881 & 1.135 \\
\hline $\begin{array}{l}\text { Effect of government } \\
\text { policies }\end{array}$ & .674 & .104 & .646 & $\begin{array}{l}6.45 \\
8\end{array}$ & .000 & .747 & .701 & 1.427 \\
\hline
\end{tabular}

Results have been further shown in Table 5, indicating that independent variables have a significant effect on the dependent variable and thus the equation of the model is shown in equation 2.

$$
\mathrm{Y}=0.144+0.042 \text { (regulatory framework) }+0.234 \text { (customer purchase) }+0.646 \text { (government policies) }
$$

\section{Findings and Discussion}

The researchers used standardized beta coefficients in measuring the strength of the individual independent variable effect to the dependent variable. It shows that the unit increase of regulatory framework resulted in a 0.042 increase of the sales of International Solar Mini-Grids, likewise, a unit increase in customer purchase has individually led to an increase of the sales by 0.234 , and finally, the unit increase of the government policies have led to increasing of the sales by 0.646 . Generally, all independent variables (regulatory framework, customer purchase and government policies) cause a significant effect on sales of international solar minigrids. However, government policy has shown to be the leading variable followed by customer purchase and regulatory framework. This research finding is congruent to the studies conducted in Kenya which observed that solar mini-grid in Kenya are affected by the shortness of lifespan of the project, government regulations and society support (Samoita et al., 2020; Ponde et al., 2019). In this regard, the tariff of the electricity is affected by government regulations as also declared by interviewees that normally government officials provide directives which affect not only sales of international solar mini-grids but also the performance of EWURA itself (Potters, 2021). Similarly, the finding of the research was also affirmed by Bishoge et al (2018) who asserted that regulations enforcement affects the investment of solar mini-grid in Tanzania.

The participant stated that:

“...The regulatory framework affects sales of International Solar Mini-Grids in Tanzania Mainland as the regulator dictates the price of electricity to the companies providing electricity" (Interview held with participant R1 from firm A on 26 $6^{\text {th }}$ May 2021). 
From this sentiment, the government indeed has the power to influence the tariff level of the electricity through politicians who normally provide various promises to the citizens who are their voters. The participant stated that:

“.... The government through its political leaders affects the tariff by encouraging citizens not to pay higher prices easily. For example, sympathizing with a citizen on cost contribution for electricity erodes the payment willingness hence sales of international solar mini-grids..." (Interview held with participant R2 from company A on 26 $6^{\text {th }}$ May 2021).

Also, the equation of the model proved that customer purchase had a positive significant impact on the sales of International Solar Mini-Grids whereby a unit increase of customer purchase resulted in a 0.234 increase in the sales of international solar mini-grids, likewise, a unit increase in customer purchase has individually led to an increase in the sales of international solar mini-grids by 0.234. The participant stated that:

“......It has been learnt that customer purchase tendency affects the sales of international solar mini-grids by ensuring the marketability of electricity. In the business arena, sales are the last and most important stage for any business as profit cannot be realized without sales......" (Interview held with participant P1 from company B on 25th May 2021).

This is valid in that sales volume is affected by the amount of price per unit of electricity hence when the project is appraised to see its feasibility or viability it may lead to an uncatchable payback period. Similarly, using other capital budgeting methods would prove that such projects will be unsustainable on the same basis congruent to Pandey (2015), thus, it is imperative that the price established should be at the level where the company will break even and earn the desired profit for the sustainability of solar energy provision. The participant stated that:

“...... Customers change in preferences and tastes and thereby decide whether to purchase or reject...in this way sales of the international solar mini-grids in Tanzania Mainland fluctuate. Thus, when such projects are appraised to examine their viability, it will fail to qualify based on delayed expected cash inflows which would otherwise uplift the NPV, PI and other capital budgeting techniques..." (Interview held with participant P2 from company B on 24 ${ }^{\text {th }}$ May 2021).

This research finding is similar to the works of Samoita et al. (2020) and Ponde et al. (2019) who found that price affects the sales of International Solar Mini-Grids in Kenya. This is so as customers decision is again affected by both intrinsic and extrinsic factors like government and other authorities. To cement this sentiment, the participant was in the opinion that:

“.........Sensible customers will compare the price of electricity with the sustainability in the installation of the solar system in their environment, even when they are ready to pay yet, they are mostly affected by the government directives whether they are constructive or not." (Interview held with participant Q1 from firm C on 26 ${ }^{\text {th }}$ May 2021).

Thus, it is difficult to explain how customer purchase alone affects the sales of International Solar Mini-Grids without linking with government interventions on the tariff of the electricity through policies and directives issues either directly or through the regulator. Similarly, the finding of the research was also affirmed by Bishoge et al. (2018) who asserted that regulations enforcement affects the investment of solar mini-grid in Tanzania including the purchasing levels of the customers.

In this regard, the tariff of electricity is affected by government regulations. Similarly, the finding of the research was also affirmed by Bishoge et al. (2018) asserting that regulations enforcement affects the investment of solar mini-grid in Tanzania. Impliedly, customer purchases affect sales of International Solar Mini-Grids in Tanzania Mainland by either reducing the sales or raising the sales. Thus, the government regulations may either positively or negatively affect the sales of international solar mini-grids depending on whether they promote or erode customers buying behaviour. To cement the above concern, the participant stated that:

".....Customer purchase tendency affects the sales of the international solar mini-grids in that sales volume is associated with decisions of customers whether to purchase electricity from our companies or not.....Thus survival and existence of the power generating companies is bestowed upon the government regulations as they significantly affect the purchasing behaviour of the customers..." (Interview held with participant Q2 from firm C on $26^{\text {th }}$ May 2021)

From this sentiment, customer purchase tendencies are important to trigger the level of sales volume in the international solar minigrids in Tanzania Mainland. What makes the customer purchase or not purchase electricity is beyond this study, however, to some extent government policies and regulations do trigger customers purchasing tendencies. Moreover, it was declared that; customers' purchase tendencies are crucial as sales are situated at the end stage of any project. Therefore, it is important to ascertain whether or not the target services suit the customers by assessing the reflection from purchasing tendencies (Managing director- Jumeme Rural Power Supply Company Limited $26^{\text {th }}$ May 2021).

The research findings mirror imaged the Mainali (2012) observations which found that income poverty, lack of credits, subsidy and institutional credibility hinder electricity sales performance. Similarly, it was learnt that renewable energy capital costs affect solar mini-grids and increase in sales of electricity (Malhotra et al,.2017). Bloomberg (2020) argued that solar mini-grids are designed for low-income families and that their customers demand is volatile because their income relies on agriculture. Fluctuating conditions of weather and crop yields seasonality, affects customer ability to pay their respective bills, hence the sales of electricity have been affected by customer income levels which are expressed in terms of the customer repulse aspect. 
In addition, from the equation of the model, it is proved that government policies had a positive significant impact on the sales of International Solar Mini-Grids whereby a unit increase of government policies resulted in a 0.646 increase in the sales of international solar mini-grids, likewise, a unit increase in government policies has individually led to an increase in sales of International Solar Mini-Grids by 0.646. The findings were similar to Bishoge et al. (2018) who revealed that government regulations and policies affect the investment of solar mini-grid in Tanzania.

Furthermore, the government being the central stakeholder of energy in the country, it is evident that these research findings are under the theory of stakeholder in that stakeholders can influence the proper functioning of the business firm. Similarly, sales of International Solar Mini-Grids in Tanzania Mainland are affected by government policies. To strengthen the above sentiment the participant stated that:

“.....Government policies affect the sales of the International Solar Mini-Grids by either promoting or inhibiting customer buying behaviour thereby affecting sales of International Solar Mini-Grids.....Thus survival and existence of these companies in business terms solely depends on the kind of government policies and their implied repercussions...." (Interview held with participant Q2 from firm C on $26^{\text {th }}$ May 2021).

\section{Conclusion}

The research objective was to investigate factors affecting sales of International Solar Mini-Grids in Tanzania Mainland. The study had three defined objectives, namely; determining regulatory framework effect on sales of International Solar Mini-Grids in Tanzania Mainland, scrutinizing the effect of Customer Purchase on sales of International Solar Mini-Grids in Tanzania Mainland, and assessing government policies effect on sales of International Solar Mini-Grids in Tanzania Mainland. The motivation for the study was because there was an evident of decline in sales of International Solar Mini-Grids in Mwanza, Dar es Salaam, and Arusha. The study revealed that government policies, more specifically energy policy, affect sales of International Solar Mini-Grids in Tanzania Mainland. In addition, the study revealed that regulatory framework particularly tariff affects sales of International Solar Mini-Grids in Tanzania Mainland. Likewise, this work revealed that customers' purchasing tendencies were significantly affecting the sales of International Solar Mini-Grids in Tanzania Mainland.

Implication, recommendations and knowledge Contribution of the study are addressed in this paragraph. The findings imply that ignoring the factors affecting sales of International Solar Mini-Grid in Tanzania Mainland might worsen the power sector and solar Mini-Grids sustainability. The research recommends that the Government of Tanzania should ensure stable legislation to create a foreseeable business environment for an investor in the power sector. EWURA, on its part, should advise the government so that chaotic policies, rules and laws be omitted immediately so that International Solar Mini-Grids offer the quality that will stimulate the demand for that electricity which will automatically trigger customers to purchase sustainably. The researchers recommend that apart from government circulars and other media, international solar mini-grids developer in Tanzania should advertise their product to boost sales. This will not only inform the customers where such service is found more rather the quality of renewable energy services. Moreover, the researchers recommend that to avoid misconception of information in renewable energy like solar provided by international companies, the government should not politicize issues on prices of solar energy to protect the sales for sustainable investment. This study offers empirical evidence on renewable energy that will be of paramount importance to other renewable energy stakeholders including researchers and academicians.

The study also proposes the areas for further research. A comparable study should be done in other mini-grids particularly on hydro and wind mini-grids because are also one of the important areas regulated by EWURA. Also, the energy policy does include petroleum and natural gas as part of the energy for access by the rural population. Study in these areas is of paramount importance to the country which needs numerous investors, and therefore, the study may assist disclosing whether present policies, legal, and regulatory framework have encouraged their access by the rural population. Also, it is important to examine factors causing many government contradicting interventions and directives to the existing energy policies in Tanzania.

Author Contributions: Conceptualization, Y.T. and C.M.; Methodology, Y.T. and C.M.; Data Collection, Y.T. and C.M.; Formal Analysis, Y.T. and C.M.; Writing - Original Draft Preparation, Y.T. and C.M.; Writing—Review and Editing, Y.T. and C.M.; Author has read and agreed to the published the final version of the manuscript.

Institutional Review Board Statement: Ethical review and approval were waived for this study, due to that the research does not deal with vulnerable groups or sensitive issues.

Data Availability Statement: The data presented in this study are available on request from the corresponding author. The data are not publicly available due to privacy.

Conflicts of Interest: The author declares no conflict of interest.

\section{References}

Abase, S. (2018). Examining Solar PV Mini-Grid System as A Complement to Grid Extension for Rural Electrification regarding Yama Community, Northern Ghana. Journal of Renewable Energy for Sustainable Development (RESD) 3 (2), 244-249.

Adom,D, Kamil, E ., and Agyem, H. J. A. (2018). Theoretical and conceptual framework: mandatory ingredients of quality research. Kumas Ghana. International Journal of Scientific Research, 7(1), 5-9. https://doi.org/10.36106/IJSR. 
Al-ghussain, L. Samu, R., \& Taylan. O. (2020). Techno-Economic Comparative Analysis of Renewable Energy Systems: Case Study in Zimbabwe. Journal of Renewable Energy for Sustainable Development 3(2) 1214-1229. https://doi.org/10.3390/inventions5030027.

Barrett, S.M. (2006). Implementation studies: time for a revival? in Budd, L., Charlesworth, J. and Paton, R. (eds) Making Policy Happen, London, Routledge/Milton Keynes, The Open University.

Bishoge, O,K., Zhang, K., and Mushi, W.G., (2018).The Potential Renewable Energy for Sustainable Development in Tanzania: A Review. Clean Technol. 2018, 1, 6; https://doi.org/10.3390/cleantechnol1010006.

Bloomberg (2020). The state of the global mini-grids market report. Trends of renewable energy hybrid in Sub-Saharan Africa, Asia and island nations. Journal of Renewable Energy for Sustainable Development 3(2) 1723-1731.

Christian, M., Hale, Z., \& Potter, E. (2021, January 14). Budget reconciliation offers Democrat's pathway to act on climate change. S\&P Global Market Intelligence.

Creswell, J. W. (2014). Research Design; Qualitative, Quantitative and mixed-method approaches; Fourth edition. New Delhi 110 044 India.

EPT. (2020). Operational Report. Dar es Salaam: Engie Power Corner Tanzania.

EWURA (2020). Electricity Sub-Sector Regulatory Performance Report for the Financial Year 2019/2020. Tanzania.

EWURA. The Energy and Water Utilities Regulatory Authority (Tariff Application and Rate Setting) Rules, 2017.

Freeman, R. E. (2015). Strategic management: A stakeholder approach. Boston: Cambridge University Press. https://doi.org/10.1017/CBO9781139192675.

Girona, M. (2019). Decentralized rural electrification in Kenya: Speeding up universal energy access. Energy Sustain. Dev.2019, $52,128-146$.

Hair, J. F., Black, C. W., Babin, B. J., \& Anderso, R. (2010). Multivariate Data Analysis (7 ed.). Upper Saddle River, New Jersey: Pearson Education.

Haradhan, M. (2018). Qualitative Research Methodology in Social Sciences and Related Subjects. Munich Personal RePEc Archive.

IBRD. (2019). Mini-Grids for Half Billion People. Market Outlook and Hand-Book for Decision Makers. Washington: The International Bank for Reconstruction and Development.

IEA., World Bank (2015). "Sustainable Energy for All 2015-Progress toward Sustainable Energy; World Bank, Washington, DC, 2015.

International Energy Agency (IEA). (2019) Facilitation of the role of photovoltaic solar energy as a cornerstone in the transition to sustainable energy systems.

IRENA (2016), Policies and regulations for private sector renewable energy mini-grids. International Renewable Energy Agency, Abu Dhabi.

JUMEME (2020). Updated New Tariff Overview Report. Mwanza. JUMEME Rural Power Supply.

Kenyan Rural Areas: A Case of KISII County. OSR Journal of Environmental Science, Toxicology and Food Technology (IOSRJESTFT) p- ISSN: 2319-2399.Volume 13, Issue 3 Ser. I (March. 2019), PP 19-61.

Kothari, C. R (2015). Research Methodology Methods and Techniques. 4th Edition New Delhi India.

Kotler, P. and Keller, K.L. (2012) Marketing Management. 14th Edition, Pearson Education.

Kumar, R. (2011). Research Methodology; A step-by-step guide for beginners. Third edition New Delhi 110044.

Kyetuza, O, Bishog. G., Zhang, L., \& Mushi, W, G. (2018). The Potential Renewable Energy for Sustainable Development in Tanzania: A Review.

Liu, M., Liu, L., Xu. S., Du, M, Liu., X., \& Zhang. Y. (2019). The Influences of Government Subsidies on Performance of New Energy Firms: A Firm Heterogeneity Perspective.

Mainali, B. (2012). Renewable Energy Market for Rural Electrification in Developing Countries: Country Case Nepal. KTH Industrial, Engineering Management Consumer Decision Making, Journal of Consumer Research, Vol. 6, pp. 123-140. https://doi.org/10.1016/j.esd.2012.03.001.

Malhotraa, A., Schmidta,T., Haelga,.L., \& Waissbein. O. (2017). Scaling up finance for off-grid renewable energy: The role of aggregation and spatial diversification in de-risking investments in mini-grids for rural electrification in India.

Marendi (2015). Public Procurement Legal Framework Implementation and Performance of State Corporations in Kenya. A Thesis Submitted in Partial Fulfillment for the Degree of Doctor of Philosophy in Supply Chain Management at the Jomo Kenyatta University of Agriculture and Technology.

Mensah, E., Ramsey-White, K., Yankey, B., \& Self-Brown, S. (2020). COVID-19 and Distance learning: Effects on Georgia State University School of Public Health students. Frontiers in Public Health, 8, 1-10. https://doi.org/10.3389/fpubh.2020.576227.

Mizerski, R. W., Golden, L. L., \& Kernan, J. B. (1979). The Attribution Process in the buying behaviour on price promotion. Journal of Marketing Science and Food Technology (2). 6, pp. 123-140.

Okello, T.M., and Kihara, A. (2019). Effect of Procurement Lifecycle on Performance of Government Ministries in Kenya. International Journal of Supply Chain and Logistics ISSN 2520-3983 (online) 3(2) pp 105 - 128, 2019. https://doi.org/10.47941/ijscl.v3i2.303.

Pandey. T. (2015). Principles of Financial Management. $8^{\text {th }}$ edition New Delhi Mumbai. 
PAOP. (2019). Off-Grid Solar Market Assessment in Tanzania. Power Africa Off-grid Project.

Ponde. E., Kahiu. R., \& Kinyua. W. (2019). Factors Affecting Sustainability of Mini-Grid Energy.

Potter, C. (2021). R-Squared vs. Adjusted R-Squared: What's the Difference? New York.

Powergen (2020). Ewura Directives On Tariff Reduction Deployment And Progress Report. Arusha: Powergen.

RENA (2020). Renewable Energy Market Analysis: Latin America Renewable energy benefits: understanding the socio-economics. International renewable energy agency.

Samoita, D., Nzila, C., Alberg, P., \& Remmen, A. (2020). Barriers and Solutions for Increasing the Integration of Solar Photovoltaic in Kenya's Electricity Mix.

Williams, N.J., Jaramillo., P., Taneja, J. (2015). An investment risk assessment of microgrid utilities for rural electrification using the stochastic techno-economic microgrid model: A case study in Rwanda.

World Bank Report (2019). Energy sector management assistance program annual report, 1818 H Street, N.W. Washington, DC 20433 USA esmap.org

Publisher's Note: SSBFNET stays neutral with regard to jurisdictional claims in published maps and institutional affiliations.

\section{(a) (1)}

(C) 2022 by the authors. Licensee SSBFNET, Istanbul, Turkey. This article is an open access article distributed under the terms and conditions of the Creative Commons Attribution (CC BY) license (http://creativecommons.org/licenses/by/4.0/).

International Journal of Research in Business and Social Science (2147-4478) by SSBFNET is licensed under a Creative Commons Attribution 4.0 International License. 